\title{
Analisis Aspek Pembiayaan Untuk Mendukung Sektor Kemaritiman yang Berwawasan Lingkungan di Indonesia
}

\author{
Mahpud Sujai a* \\ ${ }^{a}$ Pusat Kebijakan Pembiayaan Perubahan Iklim dan Multiateral, Badan Kebijakan Fiskal \\ *Email: ikp@ fiskal.kemenkeu.go.id \\ Diterima (received) 29 Desember 2017; disetujui (accepted) 30 Juli 2018; tersedia secara online (available online) 1 Agustus 2018
}

\begin{abstract}
Maritime sector is an advance development priority of the current government. Various development programs such as coastal communities and borders empowerment, maritime infrastructure development, increased production of marine fisheries and the maritime conservation has become important program priorities. However, in implementing these programs, financing and budgetary aspects remained a major constraint both in central and local government. Therefore, various breakthroughs and alternative sources of financing are needed to support the development of environmentally maritime sector. The purpose of this study is to explore the various aspects of financing that can be promoted by the stakeholders, including the government in addressing the issue of budget constraints for the development of maritime sector. Methodology that will be used in this research is descriptive analysis that will explore various alternative sources of financing as well as benchmark analysis of both cross countries analysis and cross sectoral analysis. This study is expected to provide recommendations for stakeholders, especially the government in creating a new alternative sources of financing to support the development of environmentally maritime sector.
\end{abstract}

Keywords: financing; maritime sector; climate change

\begin{abstract}
Abstrak
Sektor kemaritiman menjadi prioritas utama pembangunan dalam pemerintahan saat ini. Berbagai program pembangunan seperti pemberdayaan masyarakat pesisir dan perbatasan, pengembangan infrastruktur kemaritiman, peningkatan produksi perikanan dan pelestarian kawasan laut menjadi beberapa program penting yang menjadi prioritas. Namun dalam melaksanakan berbagai program tersebut, aspek pembiayaan dan anggaran masih menjadi kendala utama terutama terkait dengan keterbatasan anggaran pemerintah baik pusat maupun daerah. Oleh karena itu, diperlukan berbagai terobosan dan alternative sumber pembiayaan yang dapat mendukung pengembangan sektor kemaritiman yang berwawasan lingkungan. Penelitian ini memiliki tujuan untuk mengeksplorasi berbagai aspek pembiayaan yang dapat diwujudkan oleh stakeholders termasuk pemerintah dalam mengatasi permasalahan keterbatasan anggaran untuk pengembangan sector kemaritiman. Metodologi yang akan digunakan dalam penelitian ini adalah analisis deskriptif yang akan mengeksplorasi berbagai alternative sumber pembiayaan termasuk analisis benchmark baikcross countries analysis maupun cross sectoral analysis. Penelitian ini diharapkan dapat memberikan rekomendasi bagi pemangku kepentingan terutama pemerintah dalam menciptakan alternative sumber pembiayaan baru untuk mendukung pengembangan sector kemaritiman yang berwawasan lingkungan.
\end{abstract}

Kata Kunci: pembiayaan; sektor maritim; perubahan iklim 


\section{Pendahuluan}

\subsection{Latar Belakang}

Indonesia sebagai salah satu Negara maritime dan kepulauan terbesar di dunia sangat terpengaruh terhadap dampak perubahan iklim global terutama terhadap sector kelautan. Pertemuan World Ocean Conference (WOC) yang berlangsung 11-15 Mei 2009 di Manado salah satu agendanya membahas juga mengenai isu tersebut. Hal ini menjadi penting karena perubahan iklim global berdampak serius terhadap keberlangsungan sector maritim yang pada akhirnya akan berdampak pula terhadap sektor lain dalam perekonomian seperti pariwisata dan kehidupan nelayan tradisional di negeri ini. Setidaknya ada dua fenomena ekstrem terhadap lautan akibat perubahan iklim global yakni kenaikan suhu air laut dan rusaknya biota laut termasuk terumbu karang.

Perubahan iklim terjadi secara perlahan dalam jangka waktu yang cukup panjang, antara 50-100 tahun. Meskipun perlahan, dampaknya sebagian besar permukaan bumi menjadi panas dengan terjadinya peningkatan rata-rata suhu udara. Perubahan iklim merupakan sesuatu yang sulit untuk dihindari dan memberikan dampak terhadap berbagai segi kehidupan. Dampak ekstrem dari perubahan iklim terutama adalah terjadinya kenaikan temperature serta pergeseran musim. Kenaikan temperature menyebabkan es dan gletser di Kutub Utara dan Selatan mencair. Peristiwa ini menyebabkan terjadinya pemuaian massa air laut dan kenaikan permukaan air laut.

Dampak perubahan iklim tersebut sangat berpengaruh terhadap sector kelautan dan perikanan. Dampak dari perubahan iklim ini antara lain akan menurunkan produksi tambak ikan dan udang serta mengancam kehidupan masyarakat pesisir pantai, serta merusak ekosistem dan biota laut (World Ocean Conference, 2009). Kenaikan suhu air laut memiliki banyak dampak terhadap sector maritim. Pertama, berdampak terhadap ekosistem terumbu karang yang menjadi fishing ground dan nursery ground ikan yang hidup di wilayah itu.

Ikan-ikan yang hidup di daerah karang akan mengalami penurunan populasi. Hasil penelitian menyatakan bahwa akibat pemanasan global pada tahun 2050 akan mendegradasi 98 persen terumbu karang dan 50 persen biota laut (Guldberg, 2007). Kedua, terputusnya rantai makanan. Hasil penelitian menyebutkan bahwa pemanasan global (peningkatan suhu dan keasaman) akan berdampak pada hilangnya rantai makanan yang berperan sebagai katastropik yakni organism pteropoda. Dampak selanjutnya memengaruhi populasi ikan salmon, mackerel, herring, dan cod, karena organism itu sebagai sumber makanannya (Hoffman, 2008). Ketiga, naiknya permukaan air laut akan meggenangi pesisir pantai dan pulau-pulau kecil terutama di Indonesia. Hasil penelitian menyatakan bahwa naiknya permukaan air laut akibat perubahan iklim akan menyebabkan rusaknya tambak-tambak ikan dan udang di sebagian besar wilayah Indonesia dan menyebabkan kerugian yang cukup besar bagi para pembudidaya (UNDP, 2007).

Besarnya dampak perubahan iklim terhadap sector maritime tentu saja harus diatasi dan diminimalisir, sehingga perlu dilakukan berbagai upaya untuk program adaptasi dan mitigasi di sector maritim. Program adaptasi dan mitigasi tersebut tentu saja tidak akan dapat tercapai dan berhasil tanpa dukungan pembiayaan yang memadai. Oleh karena itu, kajian ini akan membahas mengenai berbagai aspek dan alternative pembiayaan perubahan iklim untuk mendukung pengembangan sector kemaritiman yang berwawasan lingkungan.

\subsection{Tujuan Penelitian}

Berdasarkan latar belakang tersebut, kajian ini diharapkan dapat menganalisis dan merumuskan berbagai alternative sumber-sumber pendanaan yang dapat digunakan untuk membiayai berbagai program adaptasi dan mitigasi di sector kelautan yang berwawasan lingkungan. Hal ini dilakukan agar sector kelautan dapat lebih terjaga kelestariannya dan untuk menjaga sector kelautan terutama pesisir pantai, terumbu karang dan perikanan dari kerusakan yang lebih parah yang disebabkan oleh perubahan iklim.

Tulisan ini bertujuan untuk mengeksplorasi beberapa aspek yang berkontribusi atau berpengaruh terhadap perumusan dan pelaksanaan kebijakan, khususnya menganalisis berbagai alternative dalam 
membiayai berbagai program dan kegiatan adaptasi dan mitigasi perubahan iklim di sector maritim di Indonesia.

\subsection{Perumusan Masalah}

Kerusakan terumbu karang, peningkatan suhu air laut, kerusakan pesisir dan abrasi pantai merupakan berbagai permasalahan yang saat ini dihadapi di sector kelautan yang disebabkan oleh perubahan iklim. Untuk mengurangi dampak kerusakan tersebut, tentu saja diperlukan berbagai jenis program perbaikan, rehabilitasi dankegiatan yang dapat mengurangi dampak perubahan iklim terhadap kerusakan tersebut. Berbagai kegiatan adaptasi dan mitigasi perubahan iklim tentu saja membutuhkan pembiayaan yang cukup besar sehingga diperlukan berbagai jenis pendanaan untuk membiayai berbagai progam dan kegiatan tersebut. Permasalahan yang terjadi adalah bagaimana program dan kegiatan tersebut dibiayai dan bagaimana sumber pendanaannya. Sehingga pertanyaan penelitian yang terungkap adalah apakah terdapat berbagai alternative sumber pembiayaan yang dapat digunakan untuk mendanai berbagai program adaptasi dan mitigasi sebagai dampak perubahan iklim di sector maritime tersebut.

\section{Metodologi}

Metodologi yang digunakan dalam kajian ini adalah metode analisis deskriptif (descriptive analysis). Tujuan dari metode analisis deskriptif adalah untuk membuat suatu penelaahan yang sistematis terhadap suatu isu dan fakta dengan cara melakukan analisis data dan fakta serta memformulasikan hipotesis dan kesimpulan tentang suatu objek penelitian.

Kajian ini dilakukan dengan menelaah berbagai literatur yang terkait dengan berbagai aspek pendanaan perubahan iklim yang dapat digunakan untuk membiayai berbagai program adaptasi dan mitigasi perubaha niklim di sector maritim. Sementara itu, data yang digunakan adalah data sekunder terkait dengan berbagai kegiata ndan program adaptasi dan mitigasi perubahan iklim yang sudah dilakukan baik di sector maritime maupun di sektor-sektor lain yang dapat digunakan sebagai benchmark. Data tersebut dapat bersumber dari instansi pemerintah seperti Kementerian KKP, BPS, Kementerian Keuangan ataupun dari berbagai sumber data lain seperti lembaga internasional dan LSM.

\section{Tinjauan Literatur}

Salah satu sektor yang tidak bisa terhindar dari perubahan iklim adalah sektor maritim, terutama untuk kerusakan terumbu karang, berkurangnya hasil perikanan tangkap dan sumber daya ikan yang terkandung di dalam laut. Hal ini akan sangat berdampak terhadap kehidupan ekonomi masyarakat miskin terutama yang hidup di pesisir pantai dan nelayan. Daerah-daerah di Indonesia yang sebagian besar merupakan kepulauan terntu saja banyak yang sangat terdampak oleh perubahan iklim ini. Sebagian besar pencaharian masyarakat di daerah pesisir akan sangat terganggu dengan berkurangnya hasil tangkapan di perairan.

Kemampuan nelayan melakukan adaptasi terhadap dampak perubahan iklim tentu saja perlu ditingkatkan dan diperkuat sehingga mereka tetap dapat mempertahankan usaha penangkapan ikan. Berdasarkan kajian yang sudah dilakukan, pilihan-pilihan upaya adaptasi yang dilakukan oleh nelayan di Indonesia antara lain dalam bentuk penganekaragaman alat tangkap, memanfaatkan hubungan sosial, perubahan daerah penangkapan dan diversifikasi sumebr pendapatan (Rindayati, Susilowati dan Hendrarto, 2013).

Penelitian tersebut juga menyatakan bahwa berdasarkan data dari Badan Meteorologi, Klimatologi dan Geofisika bahwa di berbagai wilayah pesisir dan pantai di Indonesia telah terjadi peningkatan suhu permukaan laut (Sea Surface Temperature) sekitar 0.66 0C selama 50 tahun terakhir. Hal ini mengindikasikan telah terjadi dampak perubahan iklim mengingat suhu permukaan laut merupakan salah satu unsur atau komponen dari iklim. Untuk mendalami permasalahan tersebut, para ilmuwan saat ini banyak yang menekuni bidang ilmu oceanografi yang relatif masih muda.

Ilmu Oseanografi merupakan cabang ilmu yang mempelajari lautan dengan segala aspeknnya yang merupakan perpaduan antara geology, geography, physies, chemistry, biology dan meteorology 
(Hutabarat, 2001). Dalam ilmu ini juga dipelajari tentang berbagai distribusi biota laut antara lain rumput laut, hutan bakau, terumbu karang, udang dan larva udang yang sangat ditentukan oleh kondisi iklim yang meliputi suhu, curah hujan dan angin. Daerah terumbu karang mempunyai arti yang sangat penting dan strategis bagi ekosistem perairan, sehingga harus dijaga kelestariannya, karena dapat meningkatkan produklivitas perairan. Selain itu dipelajari pula tingkat produktivitas perairan yang dipengaruhi oleh letak geografi dan sifat-sifat dari parameter fisika, kimia dan biologi perairan (Hutabarat, 2001).

Indonesia sebagai negara dengan lebih dari 70 persen wilayahnya merupakan lautan dan perairan tentu saja sangat terpengaruh dengan kondisi perairan dan kelautan sebagai akibat dari dampak perubahan iklim. Program pembangunan yang dirumuskan tentu saja harus mempertimbangkan aspek maritim sebagai salah satu sektor yang sangat vital dalam pembangunan negara. Oleh karena itu, pengelolaan sektor maritim termasuk wilayah pesisir dan laut sangatlah penting.

Pengelolaan sumberdaya pesisir di Indonesia dari sudut pandang pembangunan berkelanjutan dihadapkan pada kondisi yang bersifat mendua. Kondisi pertama, ada banyak kawasan yang belum tersentuh sama sekali oleh aktivitas pembangunan, namun pada kondisi lainnya terdapat beberapa kawasan pesisir yang telah dimanfaatkan dengan massif. Akibatnya, terlihat indikasi telah terlampauinya daya dukung atau kapasitas berkelanjutan dari ekosistem pesisir dan lautan (Helmi dan Satria, 2013). Berbagai penelitian yang dilakukan terutama terhadap nelayan dan masyarakat pesisir sebagian besar mereka sangat terpengaruh akibat perubahan ekologis yang terjadi sebagai dampak dari perubahan iklim. Selain itu, masyarakat pesisir juga sangat terpengaruh terhadap pengelolaan kawasan pesisir yang cenderung eksploitatif tanpa mempertimbangkan aspek lingkungan. Bentuk perubahan ekologis tersebut antara lain kerusakan hutan mangrove dan kerusakan terumbu karang (Helmi dan Satria, 2013).

Berbagai strategi adaptasi yang telah dilakukan oleh masyarakat pesisir dan nelayan untuk menghadapi kerusakan ekologis wilayah pesisir dan nelayan berbeda-beda dan tidak terbatas pada satu jenis adaptasi saja. Rumah tangga nelayan mengkombinasikan berbagai macam pilihan adaptasi sesuai sumberdaya yang dimilikinya. Berdasarkan hasil penelitian, pilihan-pilihan adaptasi yang dilakukan oleh nelayan antara lain: menganekaragamkan sumber pendapatan, memanfaatkan hubungan sosial, memobilisasi anggota rumah tangga, melakukan penganekaragaman alat tangkap, dan melakukan perubahan daerah penangkapan serta melakukan strategi lainnya, yakni berupa penebangan hutan mangrove secara ilegal dan mengandalkan bantuan-bantuan dari berbagai pihak (Helmi dan Satria, 2013).

Dampak lain yang timbul akibat dari perubahan iklim bagi masyarakat pesisir adalah terjadinya banjir rob atau pasang yang dialami oleh masyarakat pesisir di berbagai wilayah di Indonesia. Berbagai penelitian menyatakan bahwa rata-rata banjir rob yang terjadi dapat mencapai ketinggian 0,25 meter saat pasang tinggi terjadi. Dampak yang ditimbulkan oleh banjir rob bagi masyarakat antara lain adalah kerusakan bangunan tempat tinggal, salinitas air tanah, kerusakan lahan tambak, kehilangan lahan, serta kerusakan pada kendaraan atau peralatan kerja (Desmawan dan Sukamdi, 2012).

Program adaptasi dilakukan oleh masyarakat terutama pada bangunan tempat tinggal, ketersediaan air bersih dan pada lahan tambak. Adaptasi pada bangunan tempat tinggal antara lain meninggikan lantai rumah, meninggikan rumah dan atapnya, membuat tanggul dan membuat saluran air. Sementara itu, adaptasi pada ketersediaan air bersih antara lain menggunakan air bersih yang dipasok dari daerah lain, sedangkan adaptasi pada lahan tambak antara lain meninggikan tanggul, memasang jaring/waring dan penanaman bakau (Desmawan dan Sukamdi, 2012).

Untuk mengatasi dampak perubahan iklim di sektor maritim, diperlukan berbagai program dan kegiatan yang dapat dilakukan. Program dan kegiatan baik yang berupa adaptasi maupun mitigasi terhadap dampak perubahan iklim membutuhkan biaya yang cukup besar sehingga diperlukan berbagai alternatif pendanaan untuk membiayai berbagai program tersebut.

Dana yang digunakan dalam setiap program dan kegiatan yang berdampak terhadap kehidupan masyarakat dapat bersumber dari dua jenis dana, yaitu dana publik termasuk dana pemerintah dan dana privat atau swasta. Dana pemerintah yang disediakan terutama dalam bentuk APBN yang dialokasikan oleh Pemerintah Pusat dan dana APBD yang dialokasikan oleh Pemerintah Daerah. Sementara itu dana privat atau swasta dapat bersumber dari dana swasta dalam negeri baik dari sektor perbankan maupun dari sektor lainnya, dan dari swasta luar negeri terutama dana hibah dan CSR lembaga internasional. 
Dana yang berasal dari pemerintah pusat akan dialokasikan melalui APBN. Dana yang dialokasikan melalui APBN dapat berupa alokasi belanja melalui Kementerian atau Lembaga maupun alokasi belanja melalui dana transfer ke daerah. Alokasi dana melalui Kementerian Lembaga tentu saja dialokasikan ke dalam program dan kegiatan yang dilakukan oleh Kementerian atau Lembaga tersebut. Kementerian dan Lembaga yang mengalokasikan dana untuk program adaptasi dampak perubahan iklim sektor maritim terutama adalah Kementerian Kelautan dan Perikanan dan Kementerian Lingkungan Hidup.

Dana lain yang dialokasikan melalui APBN adalah melalui mekanisme dana transfer ke daerah. Transfer ke daerah secara garis besar terbagi menjadi dua jenis yaitu Dana Alokasi Umum (DAU) dan Dana Alokasi Khusus (DAK). DAU disalurkan secara block grant untuk membiayai kegiatan pemerintahan di daerah. Sehingga yang dapat digunakan untuk program adaptasi perubahan iklim hanyalah alokasi dana melalui Dana Alokasi Khusus (DAK).

Dana Alokasi Khusus (DAK) adalah dana yang bersumber dari pendapatan APBN yang dialokasikan kepada daerah tertentu dengan tujuan untuk membantu mendanai kegiatan khusus yang merupakan urusan daerah dan sesuai dengan prioritas nasional (UU Nomor 33 Tahun 2004). Dana Alokasi Khusus (DAK) adalah dana yang bersumber dari pendapatan APBN yang dialokasikan kepada daerah tertentu dengan tujuan untuk membantu mendanai kegiatan khusus yang merupakan urusan daerah dan sesuai dengan prioritas nasional. Besaran DAK ditetapkan setiap tahun dalam APBN. Dasar hukum Dana Alokasi Khusus (DAK) adalah UU Nomor 33 Tahun 2004 tentang Perimbangan Keuangan Antara Pemerintah Pusat dan Pemerintahan Daerah; dan PP Nomor 55 Tahun 2005 tentang Dana Perimbangan.

Dalam mengalokasikan DAK terdapat beberapa kriteria meliputi (Kemenkeu RI, 2014): a. Kriteria Umum, dirumuskan berdasarkan kemampuan keuangan daerah yang tercermin dari penerimaan umum APBD setelah dikurangi belanja PNSD, b. Kriteria Khusus, dirumuskan berdasarkan peraturan perundang-undangan yang mengatur penyelenggaraan otonomi khusus dan karakteristik daerah dan $\mathrm{c}$. Kriteria Teknis, yang disusun berdasarkan indikator-indikator yang dapat menggambarkan kondisi sarana dan prasarana, serta pencapaian teknis pelaksanaan kegiatan DAK di daerah. Penghitungan alokasi DAK dilakukan melalui dua tahapan, yaitu: penentuan daerah tertentu yang menerima DAK dan penentuan besaran alokasi DAK masing-masing daerah. Penentuan Daerah Tertentu harus memenuhi kriteria umum, kriteria khusus, dan kriteria teknis. Besaran alokasi DAK masing-masing daerah ditentukan dengan perhitungan indeks berdasarkan kriteria umum, kriteria khusus, dan kriteria teknis.

Alokasi DAK per daerah ditetapkan dengan Peraturan Menteri Keuangan. Menurut Dirjen Perimbangan Keuangan Kementerian Keuangan, arah kegiatan Dana Alokasi Khusus (DAK) antara lain digunakan untuk sektor pendidikan, kesehatan, Keluarga Berencana, infrastruktur, irigasi, air minum dan sanitasi, pertanian, lingkungan hidup, prasarana pemerintahan daerah dan kelautan dan perikanan.

DAK Kelautan dan Perikanan diarahkan untuk meningkatkan sarana dan prasarana produksi, pengolahan, peningkatan mutu, pemasaran, dan pengawasan, serta penyediaan sarana dan prasarana pemberdayaan di wilayah pesisir dan pulau-pulau kecil. Sementara itu, DAK lingkungan hidup diarahkan untuk meningkatkan kinerja daerah dalam menyelenggarakan pembangunan di bidang lingkungan hidup melalui peningkatan penyediaan sarana dan prasarana kelembagaan dan sistem informasi pemantauan kualitas air, pengendalian pencemaran air, serta perlindungan sumber daya air di luar kawasan hutan (Basyir dkk., 2015).

\section{Hasil Analisis}

Dalam rangka membiayai program adaptasi dan mitigasi perubahan iklim di sektor kelutan secara umum terdapat dua jenis sumber pembiayaan yang dapat digunakan. Sumber pembiayaan tersebut adalah melalui dana publik atau APBN/APBD dan melalui dana privat atau swasta.

Dalam hal pembiayaan mengunakan dana publik, mala alokasi secara pasti harus dilakukan melalui APBN untuk program dan kegiatan pemerintah pusat dan melalui APBD untuk program dan kegiatan pemerintah daerah. Pemerintah pusat dan pemerintah daerah tentu saja merupakan satu kesatuan dalam pembiayaan anggaran negara. Hal ini terlihat dari sebagian besar dana yang dalokasikan dalam APBD merupakan dana transfer dari pemerintah pusat. Oleh karena itu, kebijakan yang dihasilakn harus 
terkoordinasi antara pemerintah pusat dan daerah. Berikut ini adalah diagram mengenai kebijakan fiskal nasional.

Kebijakan Fiskal Nasional

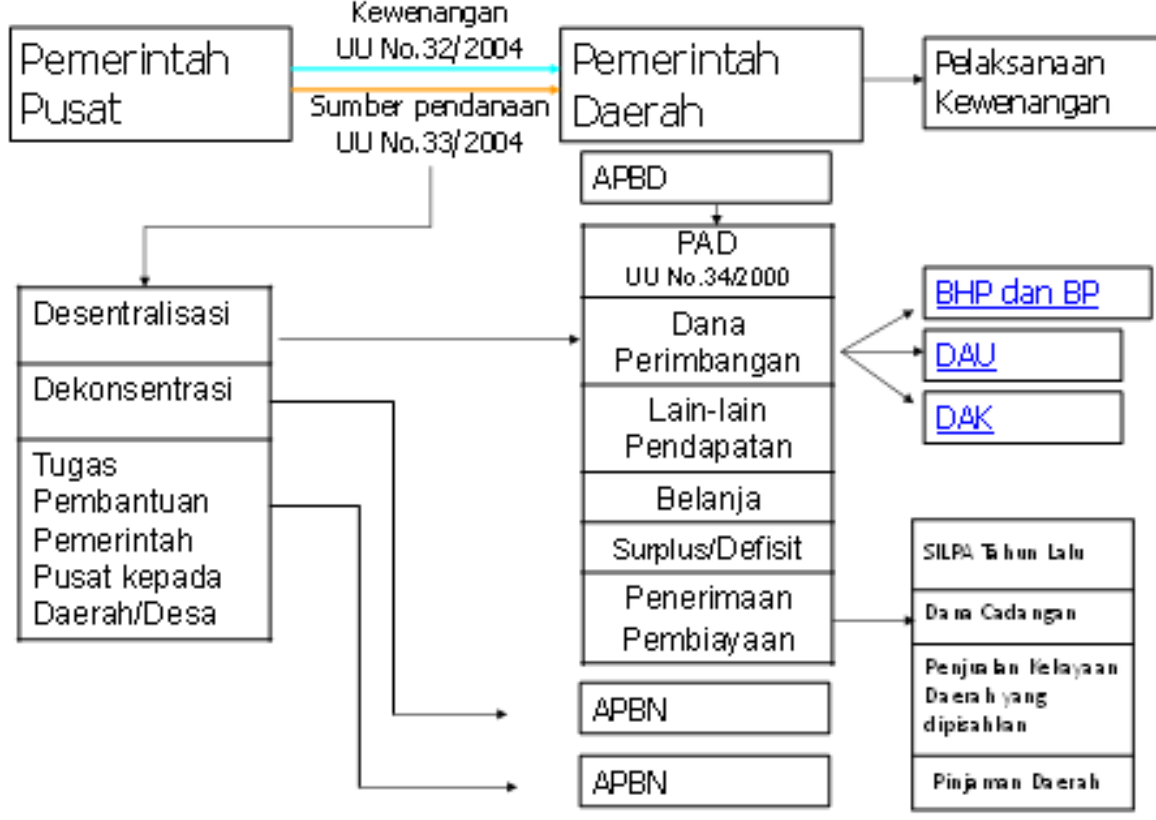

Gambar 1. Diagram Kebijakan Fiskal Nasional (Sumber: Kementerian Keuangan RI, 2015)

Berdasarkan Undang-Undang nomor 32 tahun 2004 dan Undang-Undang nomor 33 tahun 2004 dinyatakan bahwa Pemerintah Pusat menyerahkan sebagian besar kewenangannya kepada Pemerintah Daerah dalam berbagai sektor antara lain administrasi umum, pendidikan dasar, kesehatan, infrastruktur, sosial, lingkungan hidup, pertanian, perdagangan, kehutanan, kelautanm dan sektor-sektor lainnya. Sebagai konsekuensinya, Pemerintah Pusat juga memberikan sumber pendanaan kepada Pemerintah Daerah melalui mekanisme dana transfer ke daerah.Sehingga APBD yang merupakan anggaran pendapatan dan belanja daerah terbagi menjadi dua sumber utama yaitu pendapatan asli daerah (PAD) dan dana transfer dari pemerintah pusat.

Dalam hal pendanaan untuk program adaptasi perubahan iklim di sektor kelautan, dana yang berasal dari publik dapat dialokasikan dari dana APBN dan APBD. Dana APBN dialokasikan melalui alokasi anggaran di Kementerian dan Lembaga terutama Kementerian KKP dan KLHK melalui berbagai program dan kegiatan yang sudah direncanakan. Pendanaan lain dari pemerintah pusat dilakukan juga melalui dana alokasi khusus terutama untuk sektor kelautan dan sektor lingkungan hidup.

Untuk memaksimalkan alokasi dana publik bagi kegiatan adaptasi dan mitigasi perubaha iklim sektor maritim, dapat dilakukan dengan pengalokasian dana transfer namun mempertimbangkan faktor ekologis (ecological fiscal transfer). Menurut Mumbunan (2013), Ecological fiscal transfer is an allembracing instrument in that it involves transfers of general and specific-purpose as well fiscal transfers built on arrangements of revenue-sharing. It is ecological since the very idea of the instrument is to allocate fiscal resources to relevant jurisdictions for the realization of ecological public purposes at this particular level of government.

Berdasarkan definisi diatas, maka ecological fiscal transfer merupakan kombinasi antara transfer dana dari pemerintah pusat ke daerah namun mempertimbangkan faktor ekologis sebagai salah satu persyaratannya. Konsep ini memadukan public finance dengan dimensi ekologis. Secara teoretis, konsep ini merupakan area dari environmental federalism yang merupakan tanggung jawab pemerintah pusat 
yang dilimpahkan kepada pemerintah daerah dalam hal menjaga ekologis dan lingkungan agar lebih terpelihara dan berkesinambungan (responsibility assignment).

Konsep in juga merupakan kompensasi untuk positive externalities yang merupakan kompensasi pada producer/provider dari positive externalities untuk menghindari kegagalan pasar terutama dampak negatif dari kerusakan lingkungan. Contoh implementasi dari ecological fiscal transfer untuk sektor maritim misalnya pemerintah pusat akan memberikan transfer dana alokasi khusus jika pemerintah daerah menjaga kelestarian terumbu karang atau meningkatkan luas lahan hutan bakau. Hal ini dapat menjadi insentif bagi pemerintah daerah untuk menjaga ekologis di wilayahnya masing-masing. Sehingga beberapa tujuan dapat tercapai, misalnya tujuan ekologis dalam menjaga lingkungan pesisir dan laut dapat terjaga dan pemerintah daerah serta masyarakat di wilayah tersebut yang akan memperoleh manfaatnya.

Sumber pembiayaan lain yang berasal dari APBN adalah hibah yang berasal dari negara donor untuk sektor maritim di Indonesia. Pemerintah dapat melakukan pendekatan ke berbagai negara maju untuk memberikan hibah bagi sektor maritim untuk menjaga kelestarian ekologis di pesisir pantai, pulau-pulai kecil dan laut. Hibah bisa berupa program kegiatan, technical assistance maupun hibah dalam bentuk natura atau peralatan.

Pemerintah juga bisa melakukan pendekatan penggantian utang dalam bentuk kelestarian lingkungan (debt to nature swap). Debt to nature swap ini merupakan penghapusan hutang oleh pihak donor dengan syarat pemerintah menggunakan dana untuk pembayaran hutangnya untuk kegiatan-kegiatan yang bersifat pelestarian alam. Hal ini bisa dilakukan dengan menswap hutang dengan kegiatan-kegiatan seperti pelestarian terumbu karang, penanaman hutan bakau maupun pemberdayaan masyarakat pesisir dan nelayan.

Pemerintah saat ini juga telah membentuk Indonesia Climate Change Trust Fund (ICCTF) yang merupakan dana perwalian dari negara-negara maju yang digunakan untuk kegiatan adaptasi dan mitigasi perubahan iklim. Dana ini merupakan hibah dana perwalian dari negara-negara maju yang dikumpulkan dan dikelola oleh pemerintah Indonesia. ICCTF dapat mengalokasikan sebagian dana hibahnya untuk kegiatan-kegiatan adaptasi dan mitigasi di sektor maritim.

Selain yang berasal dari dana publik atau pemerintah, terdapat berbagai alternatif pembiayaan lain yang bersumber dari dana privat atau swasta. Dana swasta tersebut secara garis besar dapat dibagi menjadi dua jenis, yaitu dana swasta dalam negeri dan dana swasta yang bersumber dari luar negeri. Dana swasta yang bersumber dari dalam negeri dapat berupa pembiayaan dari sektor perbankan, pembiayaan dari sektor non perbankan dan pembiayaan yang bersumber dari dana Corporate Social Responsibility (CSR).

Dana perbankan biasanya merupakan dana pinjaman yang dilakukan oleh berbagai lembaga maupun LSM untuk melakukan kegiatan sosial berupa pelestarian lingkungan dan kegiatan masyarakat. Biasanya untuk dana perbankan sangat sulit dan harus memiliki penjamin, sehingga biasanya selalu ada pihak yang menjadi penjamin kegiatannya terutama dari lembaga-lembaga donor. Sementara itu untuk dana non bank biasanya dapat berupa dan hibah dari masyarakat, organisasi lokal maupun dana masyarakat sendir yang berswadaya dalam menjaga kelestarian lingkungan.

Salah satu alternatif lain yang cukup feasible untuk digunakan adalah dana Corporate Social Responsibility (CSR). Dana CSR merupakan dana yang disisihkan terutama oleh perusahaan besar untuk memenuhi kewajiban sosialnya kepada masyarakat. Dana CSR dapat dialokasikan untuk membiayai berbagai kegiatan pelestarian lingkungan dalam hal ini menjaga kelestarian lingkungan pesisir, menanam hutan bakau dan menjaga kelestarian terumbu karang.

Berbagai contoh dari dana CSR yang sudah dilakukan di sektor maritim ini antara lain adalah penanaman 5000 mangrove di Desa Pasir, Kecamatan Mempawah Hilir, Kabupaten Mempawah, yang merupakan kolaborasi masyarakat sipil, Pemerintah Daerah Mempawah, dan unsur swasta dalam hal ini CSR perusahaan. Contoh penggunaan dana CSR lainnya antara lain penanaman mangrove 1 juta pohon di daerah pantai utara pulau Jawa, pelestarian terumbu karang di wilayah Maluku dan konservasi penyu di wilayah Sumatera Barat.

Sumber pendanaan lain yang berasal dari dana privat dapat bersumber juga dari dana luar negeri (global fund). Dana global ini merupakan dana yang dikumpulkan oleh masyarakat internasional dalam rangka mengatasi dampak perubahan iklim dan pelestarian lingkungan. Dana global yang saat ini tersedia 
antara lain adalah dalam bentuk skema Global Environment Fund, Green Climate Fund dan Skema Fund lainnya yang dikembangkan di forum-forum internasional. Dana-dana global tersebut merupakan bentuk tanggung jawab masyarakat internasional yang dikumpulkan untuk mengatasi dampak perubahan iklim. Namun dalam penyalurannya, diperlukan berbagai persyaratan dan prakondisi yang sangat ketat dalam rangka memperoleh dana tersebut.

Berbagai sumber pendanaan tersebut, apabila dioptimalkan penggunaannya dapat menjadi sumber dana yang cukup besar dalam melestarikan lingkungan dan mengatasi dampak perubahan iklim di sektor maritim. Mengingat Indonesia merupakan negara kepulauan dengan banyak pulau-pulau kecil dan wilayah pesisir pantai, maka dampak perubahan iklim akan sangat berpengaruh terhadap negara dan masyarakat Indonesia baik dari sisi sosial, ekologis, lingkungan maupun ekonomi masyarakat.

\section{Kesimpulan dan Rekomendasi}

Sektor maritim merupakan sektor yang sangat penting bagi Negara Indonesia dengan luas wilayah lebih dari 70 persen merupakan wilayah perairan.

Berdasarkan penelitian, terjadi peningkatan suhu rata-rata air laut hingga 0,25 derajat selama kurun waktu 50 tahun terakhir. Hal tersebut berdampak luas terhadap kehidupan perikanan di lautan, terumbu karang dan masyarakat pesisir.

Perubahan iklim berdampak negatif terhadap sektor maritim terlihat dengan peningkatan permukaan air laut, pengurangan luas wilayah pesisir yang sangat mengganggu perekonomian masyarakat. Dampak perubahan iklim tersebut harus diminimalisir dengan berbagai program dan kegiatan adaptasi dan mitigasi perubahan iklim.

Diperlukan dana yang cukup besar dalam membiayai berbagai program pelestarian lingkungan laut dan adaptasi perubahan iklim sehingga diperlukan berbagai alternatif sumber pendanaan untuk membiayai programn kegiatan tersebut.

Perlu optimalisasi sumber-sumber pendanaan yang maksimal sehingga dapat digunakan untuk melestarikan lingkungan pesisir dan laut serta melakukan berbagai kegiatan adaptasi dan mitigasi perubahan iklim.

\section{Daftar Pustaka}

Basyir, Hamzah, A., \& Syahnur, S. (2015). Faktor-Faktor Yang Mempengaruhi Kemiskinan Di Provinsi Aceh. Jurnal Ilmu Ekonomi: Program Pascasarjana Unsyiah, 3(1), 57-70.

Desmawan, B. T., \& Sukamdi, S. (2012). Adaptasi masyarakat kawasan pesisir Terhadap banjir rob di kecamatan sayung, Kabupaten demak, jawa tengah. Jurnal Bumi Indonesia, 1(1).

Helmi, A., \& Satria, A. (2013). Strategi adaptasi nelayan terhadap perubahan ekologis. Makara, Sosial Humaniora, 16(1), 68-78.

Humas Kemenko Maritim (2017). Jaga Kelestarian Kawasan Pesisir, Pemerintah Gandeng Pihak Swasta Tanami Mangrove. [online]. Tersedia di: https://maritim.go.id/jaga-kelestarian-kawasanpesisir-pemerintah-gandeng-pihak-swasta-tanami-mangrove/, [diakses: 19 Februari 2019]

Hutabarat, S. (2001). Pengaruh Kondisi Oseanografi Terhadap Perubahan Iklim, Produktivitas dan Distribusi Biota Laut. Pidato Pengukuhan. Semarang, Indonesia: Fakultas Perikanan dan Ilmu Kelautan, Universitas Diponegoro.

Lasabuda, R. (2013). Pembangunan wilayah pesisir dan lautan dalam perspektif Negara Kepulauan Republik Indonesia. Jurnal Ilmiah Platax, 1(2), 92-101.

Mumbunan, S. (2011). Ecological fiscal transfers in Indonesia. Disertation. Leipzig, Germany: Von der Wirtschaftswissenschaftlichen Fakultät, der Universität Leipzig.

Republik Indonesia. (2005). Undang-Undang Republik Indonesia Nomor 33 Tahun 2004 Tentang Perimbangan Keuangan Antara Pemerintah Pusat Dan Pemerintahan Daerah. Lembaran Negara Republik Indonesia Tahun 2004 Nomor 126. Jakarta, Indonesia: Sekretariat Negara Republik Indonesia. 
Rindayati, H., Susilowati, I., \& Hendrarto, B. (2013). Adaptasi Nelayan Perikanan Tangkap Pulau Moro Karimun Kepulauan Riau Terhadap Perubahan Iklim. Dalam Seminar nasional Pengelolaan Sumberdaya Alam dan Lingkungan "Optimasi Pengelolaan Sumberdaya Alam dan Lingkungan dalam Mewujudkan Pembangunan Berkelanjutan". Semarang, Indonesia: 27 Agustus 2013 (pp. 265272)

Ring, I. (2002). Ecological public functions and fiscal equalisation at the local level in Germany. Ecological Economics, 42(3), 415-427.

WWF Indonesia (2015). Hijaukan Pesisir Kalbar, Tanam 5000 Bibit Mangrove. [online]. Tersedia di: http://www.wwf.or.id/?41783/Greening-The-Coast-of-West-Borneo-By-Planting-5000-Mangroves, [diakses: 19 Februari 2019]. 